\title{
PERAN PAUD DALAM MENGOPTIMALKAN TUMBUH KEMBANG ANAK USIA DINI DEMI MEMBANGUN MASA DEPAN BANGSA
}

\author{
Desni Yuniarni \\ Universitas Tanjungpura Pontianak \\ yuniarnidesni@yahoo.com
}

\begin{abstract}
ABSTRAK
Panak usia dini (PAUD) memainkan peran yang penting dalam pendidikan di Indonesia, yang nantinya dapat turut meningkatkan kualitas sumber daya manusia di Indonesia. Tujuan pendirian PAUD adalah memfasilitasi pertumbuhan dan perkembangan anak sedini mungkin pada aspek fisik, psikis dan sosial secara menyeluruh, sehingga diharapkan anak akan tumbuh dan berkembang secara optimal di semua aspek perkembangannya. Berkaitan dengan generasi emas yang sedang dipersiapkan untuk menyonsong '100 Tahun Kemerdekaan Indonesia', dengan adanya PAUD diharapkan anak-anak usia dini yang masih dalam fase golden age ini dapat tampil sebagai tunas-tunas bangsa terbaik, berakhlak mulia, berkarakter, dan cerdas dan dapat menjadi dapat generasi emas yang produktif dan kompetitif secara global serta dapat membangun masa depan bangsanya dengan lebih baik lagi.
\end{abstract}

KATA KUNCI: PAUD, Tumbuh Kembang, Anak Usia Dini

\section{PENDAHULUAN}

Indonesia akan merayakan ulang tahun emasnya pada tahun 2045. Pencanangan generasi emas yang disampaikan oleh Menteri Pendidikan dan Kebudayaan, Muhammad Nuh, pada saat memperingati hari pendidikan nasional (Hardiknas) pada tahun 2012, mendorong bangkitnya generasi emas Indonesia. Untuk mendorong bangkitnya generasi emas, Menteri Pendidikan dan Kebudayaan pada saat itu menyatakan, pada periode tahun 2010 sampai tahun 2035, pemerintah akan melakukan investasi besar-besaran dalam bidang pengembangan sumberdaya manusia (SDM) sebagai upaya menyiapkan generasi 2045, yaitu 100 tahun Indonesia merdeka.

Langkah nyata yang dilakukan adalah membuka akses seluas-luasnya kepada seluruh anak bangsa untuk memasuki dunia pendidikan; mulai dari pendidikan anak usia dini (PAUD) sampai keperguruan tinggi.

Pentingnya PAUD diperkuat oleh berbagai penelitian terbaru tentang otak. Pada saat bayi dilahirkan ia sudah dibekali Tuhan dengan struktur otak yang lengkap, namun baru mencapai kematangannya setelah di luar kandungan. Bayi yang baru lahir memiliki lebih dari 100 milyar neuron dan sekitar satu trilyun sel glia yang berfungsi sebagai perekat serta synap (cabangcabang neuron) yang akan membentuk bertrilyun-trilyun sambungan antar neuron yang jumlahnya melebihi kebutuhan. Synap ini akan bekerja sampai usia 5-6 tahun. Banyaknya jumlah sambungan tersebut mempengaruhi pembentukan kemampuan otak sepanjang hidupnya. Pertumbuhan jumlah jaringan otak dipengaruhi oleh pengalaman yang didapat anak pada awalawal tahun kehidupannya, terutama pengalaman yang menyenangkan. Pada fase perkembangan ini akan memiliki potensi yang luar biasa dalam mengembangkan kemampuan berbahasa, matematika, keterampilan berpikir, dan pembentukan stabilitas emosional.

Pendidikan anak usia dini tidak sekedar berfungsi untuk memberikan pengalaman belajar kepada anak, tetapi yang lebih penting berfungsi untuk mengoptimalkan perkembangan otak. 
Pendidikan anak usia dini sepatutnya juga mencakup seluruh proses stimulasi psikososial dan tidak terbatas pada proses pembelajaran yang terjadi dalam lembaga pendidikan. Artinya, pendidikan anak usia dini dapat berlangsung dimana saja dan kapan saja seperti halnya interaksi manusia yang terjadi di dalam keluarga, teman sebaya, dan dari hubungan kemasyarakatan yang sesuai dengan kondisi dan perkembangan anak usia dini.

\section{TUMBUH KEMBANG ANAK USIA DINI}

Pertumbuhan dan perkembangan anak harus diperhatikan sedari kecil. Pertumbuhan dan perkembangan merupakan dua hal yang berbeda, namun saling berkaitan dan sulit dipisahkan.

Pertumbuhan berkaitan dengan perubahan kuantitatif, yaitu peningkatan ukuran dan struktur. Sedangkan perkembangan berkaitan dengan perubahan kualitatif dan kuantitatif. Dapat didefinisikan sebagai deretan progresif dari perubahan yang teratur dan koheren. Progresif menandai bahwa perubahan terarah. Teratur dan koheren menunjukkan adanya hubungan nyata antara perubahan yang terjadi dan yang telah mendahuluinya (Hurlock, 2013).

Elizabeth Hurlock mengemukakan jenis-jenis perubahan selama proses perkembangan adalah sebagai berikut:

1. Perubahan ukuran

Contohnya adalah perubahan dalam hal penambahan tinggi badan dan berat badan. Seorang anak dikatakan memiliki perkembangan yang normal, apabila adanya kesesuaian antara usianya dengan berat badan dan tinggi badan rata-rata anak yang seusia dengannya. Standar perkembangan ini bisa diperoleh dari Kartu Menuju Sehat (KMS) yang diberikan di posyandu, puskesmas dan di poli tumbuh kembang anak lainnya. Perubahan dalam ukuran juga berarti adanya perubahan dalam kegiatan mental seseorang, seperti kemampuan dalam mengingat sesuatu, menyelesaikan masalah, beradaptasi dan lain sebagainya.

2. Perubahan proporsi

Adanya perubahan dalam proporsi merupakan salah satu ciri terjadinya perubahan dalam perkembangan. Proporsi tersebut dapat berarti perubahan dalam proporsi kemampuan berpikir dan perubahan dalam proporsi kemampuan lainnya. Contohnya anak usia 0-2 tahun berada pada tahap kognitif sensorimotor. Kemudian pada usia 2-4 tahun, ia akan mengalami perubahan dalam proporsi kognitifnya, dari sensorimotor menjadi praoperasional.

3. Hilangnya ciri lama

Perubahan dalam perkembangan juga berarti hilangnya ciri-ciri perkembangan suatu fase berganti dengan fase selanjutnya. Contohnya hilangnya ciri-ciri anak usia 0-1 yang berada pada fase oral, seperti suka menghisap jari pada anak usia 2 tahun. Usia 2 tahun, pada umumnya anak tidak lagi suka menghisap jarinya.

4. Mendapatkan ciri baru

Ciri baru yang muncul pada diri anak menandai adanya proses perkembangan dalam dirinya, contohnya, semula anak hanya bisa mengucapkan 2-3 kata, sejalan dengan usianya, ia dapat menyebutkan kalimat lengkap yang lebih dari 3 kata.

Perkembangan memiliki karakteristik yang dapat diramalkan. Hal ini berlaku tidak hanya untuk perkembangan mental tetapi juga untuk perkembangan fisik. Berikut ini terdapat lima karakteristik perkembangan yaitu:

1. Adanya kesamaan dalam pola perkembangan

Setiap anak memiliki pola perkembangan yang sama dari satu tahap menuju tahap berikutnya. Contohnya, sebelum seorang anak dapat berjalan, ia akan melalui tahap belajar berdiri. 
2. Perkembangan bergerak dari tanggapan yang umum menuju tanggapan khusus

Contohnya disini adalah seorang bayi pada awalnya hanya bisa menangis sebagai reaksi ketidaksukaannya/ketidaknyamanannya terhadap sesuatu. Reaksi menangis tersebut bersifat umum. Seiring dengan bertambahnya usia, bayi akan menunjukkan berbagai macam reaksi terhadap kondisi yang tidak disukainya, seperti membalikkan badan, berteriak keras-keras dan lain sebagainya (sifat-sifat khusus).

3. Perkembangan berlangsung secara berkesinambungan

Perkembangan adalah suatu tahapan yang tidak terputus-putus, selalu ada kelanjutan dalam setiap tahapan. Setiap anak yang lahir normal akan mengalami tahapan perkembangan kemampuan kognitif yang berkelanjutan, seperti yang dikemukakan oleh Piaget misalnya, yaitu tahapan sensorimotor, dilanjutkan menjadi praoperasional kemudian menjadi kongkret operasional dan menjadi formal operasional.

4. Berbagai bidang berkembang dengan kecepatan berbeda

Contohnya setiap anak akan berbeda-beda perkembangannya dalam hal perkembangan bicaranya. Ada anak yang bisa berbicara lancar di usia 12 bulan dan ada anak yang lancar bicara di usia 18 bulan. Perbedaan tersebut adalah hal yang wajar selama berada pada rentang normal perkembangan bicara anak. Perbedaan tersebut dipengaruhi oleh banyak faktor diantaranya adalah stimulasi, gizi dan tingkat kecerdasan anak. Anak yang memperoleh gizi yang baik, cerdas dan selalu distimulasi (dibacakan buku cerita, diajak bernyanyi, diajak bercakap-cakap) akan cenderung lebih cepat bicara lancar daripada anak yang kurang distimulasi, gizinya kurang baik atau tingkat kecerdasannya di bawah rata-rata.

5. Ada korelasi dalam perkembangan

Perkembangan kemampuan berpikir seorang anak ditandai dengan bertambahnya perbendaharaan kata yang dimilikinya.

Dalam perkembangan, dikenal istilah masa peka. Masa peka ialah masanya suatu fungsi mudah/peka untuk dikembangkan. Masa peka merupakan masa yang terjadi dalam perkembangan pada saat-saat tertentu. Masa peka ini diperkenalkan dalam dunia pendidikan oleh Maria Montessori. Ketika seorang anak berada pada masa pekanya, maka ia akan lebih mudah mempelajari sesuatu dibandingkan jika ia diminta mempelajari sesuatu padahal masa pekanya terhadap hal tersebut sudah terlewati.

Montessori menemukan 9 masa peka anak. Kesembilan masa peka tersebut adalah sebagaimana dikemukakan oleh Sudono (2006) berikut ini:

Tabel Masa Peka Perkembangan Anak oleh Montessori

\begin{tabular}{|c|l|l|}
\hline No. & \multicolumn{1}{|c|}{ Usia anak } & \multicolumn{1}{c|}{ Masa Peka } \\
\hline 1. & $0-3$ tahun & Masa penyerapan total; perkenalan dan pengalaman panca indra sensorik \\
\hline 2. & $1,5-3$ tahun & Perkembangan Bahasa \\
\hline 3. & $1,5-4$ tahun & $\begin{array}{l}\text { Perkembangan koordinasi antara mata dan otot-ototnya, perhatian anak ke } \\
\text { benda-benda kecil }\end{array}$ \\
\hline 4. & $2-4$ tahun & $\begin{array}{l}\text { Perkembangan dan penyempurnaan gerakan-gerakan. Perhatian anak pada } \\
\text { hal-hal yang nyata. }\end{array}$ \\
\hline 5. & $2,5-6$ tahun & Penyempurnaan penggunaan panca indra \\
\hline 6. & $3-6$ tahun & Peka terhadap pengaruh orang dewasa \\
\hline 7. & $3,5-4,5$ tahun & Mulai coret-coret \\
\hline 8. & $4-4,5$ tahun & Indra peraba mulai berkembang \\
\hline 9. & $4,5-5,5$ tahun & Mulai tumbuh minat baca \\
\hline
\end{tabular}


Dari masing-masing masa peka tersebut, orang tua atau guru dapat memilih permainan edukatif (APE) yang sesuai dengan tahapan perkembangan anak, contohnya anak-anak pada usia 0-3 tahun akan lebih tepat memainkan permainan yang terbuat dari plastik lentur dan halus atau bisa juga alat permainan yang terbuat dari kain, seperti boneka. Ketika usianya terus bertambah, seiring juga bertambahnya kecerdasannya, maka anak boleh diperkenalkan pada APE yang mempunyai tingkat kerumitan tertentu. Montessori menggunakan tiga prinsip utama untuk memberikan APE pada anak, yaitu:

Pertama, pendidikan usia dini (early childhood). Prinsip ini menekankan pada perhatian secara penuh terhadap kebiasaan dan pengetahuan dasar yang dibutuhkan anak sesuai dengan tingkat perkembangannya. Bahkan, cara pembelajaran dan cara bermainnya juga disesuaikan dengan cara belajar anak. berdasarkan penelitiannya, Montessori menemukan bahwa anak-anak mampu belajar dan bermain sendiri yang unik dan khas serta bersifat refleks, spontan dan tanpa tekanan.

Kedua, lingkungan pembelajaran (the learn environment). Prinsip ini menekankan pada kesesuaian antara bermain dan belajar dengan lingkungan. Caranya, Montessori mengajak anakanak membantu pekerjaan orang tua yang ringan-ringan, seperti mencuci baju, mencuci mainan, perabotan atau sekedar memandikan boneka.

Ketiga, peran guru (the role of the teacher). Prinsip ini menekankan pada peranan guru dalam pembelajaran dan permainan anak. Montessori menegaskan bahwa tugas orang tua dan guru hanya sebatas fasilitator. Artinya guru harus melayani kebutuhan anak. disamping itu, tugas guru dan orang tua adalah mengemas berbagai permainan dan pembelajaran sehingga menyenangkan bagi anak. Atas dasar rasa senang inilah rasa ingin tahu anak akan terus berkembang, sehingga ada komunikasi yang intensif antara anak dan orang tua atau guru.

Orang tua dan guru harus memiliki pengetahuan mengenai bagaimana memilih mainan yang mencerdaskan anak. Dengan kata lain, sebelum memberikan jenis permainan tertentu kepada anak, pastikan bahwa jenis permainan itu adalah pilihan terbaik untuk pengembangan kecerdasan anak. Berikut ini akan dijelaskan bagaimana memilih jenis-jenis permainan yang mempunyai nilai edukasi yang tinggi dan bebas dari dampak negatif.

1. Sesuaikan dengan perkembangan anak

Montessori mengemukakan bahwa setiap anak pasti akan masa peka atau periode sensitif. Setiap masa peka tersebut, anak-anak membutuhkan permainan yang berbeda-beda. Jika permainan tidak sesuai dengan masa peka atau periode sensitif yang dilewatinya, maka permainan tersebut tidak akan membawa dampak apa-apa, kecuali anak menjadi benci terhadap permainan tersebut.

Jangan salahkan anak jika ia menolak atau tidak tertarik pada jenis permainan tertentu, padahal itu sangat penting bagi anak. Anak pada masa itu, tidak membutuhkan jenis permainan yang diberikan guru dan orang tua. Ia mempunyai keinginan tersendiri untuk bermain sesuai dengan kebutuhannya.

William Crain meringkas masa peka Montessori menjadi lima periode sensitif. Kelima periode sensitif tersebut adalah sebagai berikut:

a. Periode keteraturan

Periode keteraturan adalah masa ketika anak senang beraktivitas secara teratur. Masa ini berlangsung dari lahir sampai pada usia 3 tahun, contohnya anak senang mengambil benda mainannya dan mengembalikannya seperti semula; jika ia melihat cangkir tidak pada tempatnya, ia senang mengembalikan pada tempat seperti biasanya. Jika tidak, ia akan menangis sebagai tanda tidak menyukai kejadian itu. Bahkan, seringkali anak bisa 
"marah" ketika melihat seseorang memindahkan barang mainannya tidak pada tempatnya, meskipun diletakkan pada tempat yang lebih baik (Crain, 2007).

Menurut Motessori pada usia tiga tahun pertama, anak-anak memperoleh prinsip orientasi dari lingkungan tentang apa-apa yang harus mereka kuasai di kemudian hari. Oleh karena itu, pada masa ini pemilihan permainan yang paling sesuai adalah permainan yang membutuhkan keteraturan.

b. Periode detail

Periode detail adalah masa ketika anak senang mengamati objek (benda mainan) dengan sangat detail selama beberapa detik. Contohnya jika kita menunjukkan selembar gambar, anak-anak seolah tidak memperhatikan objek-objek dari gambar tertentu yang kita anggap penting. Tetapi, mereka justru tertarik pada pernak-pernik gambar yang kecil dan tersembunyi di balik gambar tersebut. Hal ini menunjukkan bahwa dunia anak sangat berbeda dengan dunia orang dewasa. Oleh Karena itu, memaksa anak sesuai dengan kehendak orang dewasa adalah perbuatan yang tidak tepat.

Pemilihan permainan yang tepat pada masa ini adalah permainan yang mempunyai tingkat kedetailan tertentu, sehingga mampu mengasah ketajaman pengamatan detail anak. Oleh karena itu, jangan berikan jenis-jenis permainan yang mempunyai detail kurang baik. Usahakan memilih permainan yang mempunyai tingkat kedetailan yang sangat indah dan menawan.

c. Periode penggunaan tangan

Pada masa ini, anak senang memegang, meremas, menarik dan menyobek. Bahkan, tanpa diajari ia akan berusaha membuka dan menutup objek dan memasukkannya ke dalam kotak yang tersedia. Periode ini berlangsung selama 18 bulan hingga 3 tahun (Crain, 2007). Dua tahun kemudian, anak-anak mulai meningkatkan gerakan indra seutuhnya, seperti memasukkan jari ke dalam mulut. Dalam kondisi tersebut, maka pemilihan mainan yang tepat pada masa ini adalah permainan yang aman sehingga tidak melukai tangan anak ketika meremas, seperti permainan yang terbuat dari plastik dan mainan lainnya. Di samping itu, pastikan bahwa bahan mainan tersebut tidak beracun, sehingga aman ketika dimasukkan ke dalam mulut anak. Dalam hal ini, perlu diperhatikan pula bahan pewarna atau cat yang terdapat pada permainan tesebut. Cat atau pewarna yang aman adalah non-toxid.

d. Periode berjalan

Periode yang mudah diamati adalah periode berjalan. Bagi anak-anak, berjalan merupakan kegiatan yang tak dapat dibendung oleh siapapun. Menurut Montessori, anak akan dapat berjalan dengan sendirinya tanpa dibantu untuk berjalan. Awasi anak untuk menemukan caranya sendiri dalam berjalan. Hingga suatu saat ia benar-benar dapat berjalan sendiri dengan penuh percaya diri. Pilihan jenis permainan yang tepat untuk kepekaan berjalan adalah permainan berbasis kegiatan. Sebab permainan ini banyak menekankan pada perkembangan motorik kasar.

e. Periode bahasa

Periode kepekaan bahasa adalah masa ketika anak sedang haus akan hasratnya menyerap kata-kata dan gramatika. Pada masa ini, anak-anak sangat cepat dan begitu mudah dalam memahami maksud dari kata atau bahasa. Menurut Montessori, periode ini merupakan periode paling kompleks. Sebab, anak-anak bukan saja hanya belajar kata-kata, melainkan mengenal aturan atau gramatika bahasa. Oleh karena itu, kita tidak boleh salah 
berbahasa dengan anak, jika kesalahan ini sampai terjadi, maka anak pun akan salah menangkap.

Pemilihan jenis permainan yang tepat pada masa peka bahasa ini adalah memberikan kata-kata terstruktur yang jelas dan lugas sehingga mudah dipahami dan ditirukan anak.

Hal terpenting disini adalah guru dan orang tua mampu memilihkan dan memberikan jenis permainan tertentu yang sesuai dengan setiap masa peka di atas. Oleh karena itu jangan sampai memilihkan permainan yang tidak sesuai dengan masa peka anak.

2. Aman bagi anak

Kriteria kedua dalam memilih alat permainan yang mencerdaskan adalah sifat aman. Aman dalam artian tidak membahayakan fisik maupun psikis anak. Bahan baku untuk membuat alat permainan adalah faktor utama aman atau tidaknya sebuah alat permainan digunakan. Terlebih lagi untuk anak berusia 0-3 tahun, maka pemilihan alat permainan harus lunak, tanpa sisi tajam dan lembut. Disinilah perlunya perhatian orang tua untuk menyesuaikan jenis-jenis permainan anak. Jika memungkinkan, jauhkan anak-anak pada usia dini dari benda-benda tajam.

Jika bermainnya di lapangan atau alam terbuka, maka faktor aman ditentukan oleh tanaman beracun dan binatang berbisa. Sebelum menggunakan lapangan atau alam terbuka sebagai area bermain anak-anak, pastikan lapangan atau alam terbuka itu bebas dari binatang melata yang mematikan atau serangga liar yang berbahaya. Hal ini penting diperhatikan karena kreativitas anak di alam terbuka sangat sulit dikendalikan. Ia akan memegang apa saja yang dianggapnya baru, bahkan meremas dan memasukkan ke dalam mulutnya.

Dari uraian di atas, dapat disimpulkan bahwa faktor aman dalam permainan anak mencakup dua hal, yaitu aman secara bendawi dan aman secara hakiki. Aman secara bendawi adalah faktor keamanan seperti tidak melukai, tidak meracuni, tidak mencemari dan lain sebagainya. Sedangkan aman secara hakiki adalah sumber bahan mainan itu sendiri, seperti dibuat dari bahan yang baik serta dalam pemberiannya diliputi kasih sayang dan perhatian.

\section{Menyenangkan}

Kriteria selanjutnya dalam memilih permainan untuk anak adalah menyenangkan. Namun, tidak semua alat permainan yang menyenangkan dapat diberikan kepada anak. karena itu meskipun menyenangkan, permainan itu harus mencerdaskan. Pemilihan permainan yang menyenangkan dan mencerdaskan tidak terlepas dari masa peka yang dilewati anak.

Berkembangnya berbagai kemampuan pada anak adalah sebuah proses. Hal ini dapat didorong dengan rangsangan/stimulasi yang sesuai dengan perkembangan anak usia dini, yaitu melalui kegiatan bermain. Bermain adalah pekerjaan anak (Shoba Dewey Chugani, 2009). Dalam kamus besar bahasa Indonesia disebutkan bahwa yang dimaksud bermain adalah berbuat sesuatu untuk menyenangkan hati (dengan menggunakan alat-alat tertentu atau tidak). Sementara yang dimaksud dengan belajar adalah berusaha memperoleh kepandaian atau ilmu Suyadi (2009). Hal ini sejalan dengan pendapat Irawati (dalam Yuliani Nurani Sujiono dan Bambang Sujiono, 2010), bahwa bermain adalah kebutuhan semua anak, terlebih lagi bagi anak-anak di rentang usia 3-6 tahun. Bermain adalah suatu kegiatan yang dilakukan oleh anak dengan atau tanpa menggunakan alat yang menghasilkan pengertian dan memberikan informasi, memberi kesenangan dan mengembangkan imajinasi anak secara spontan dan tanpa beban.

Berdasarkan berbagai pendapat diatas, dapat disimpulkan bahwa kondrat anak adalah bermain, dimana setiap anak tidak bisa dipisahkan dengan bermain. Bermain sangat penting bagi anak usia dini, karena dalam bermain, semua aspek perkembangannya terstimulasi dengan baik. 
Anak dapat mengembangkan seluruh aspek perkembangannya melalui berbagai macam kegiatan bermain. Oleh karena itu, dalam konsep pembelajaran anak usia dini, dikenal istilah bermain seraya belajar.

Dalam bukunya, Metode Pengajaran di Taman Kanak-kanak, Moeslichatoen R, (2004:24), terdapat beberapa nilai bermain bagi anak usia dini:

1) Bermain memberi kebebasan anak untuk bertindak

Dalam bermain, anak terstimulasi kemampuannya dalam berpikir pada saat memainkan permainan tersebut. Contohnya ketika anak bermain peran menjadi seorang dokter, dimana temannya yang lain menjadi pasien. Anak akan berperan sebagai layaknya dokter, seperti menanyakan penyakit/apa keluhan pasien, memeriksa kondisi pasien, menuliskan resep, memberikan obat dan lain sebagainya. Untuk dapat memerankan peran dokter seperti itu, anak harus memiliki pengetahuan tentang peran dan tugas seorang dokter.

Pada saat berperan sebagai dokter, anak juga menunjukkan rasa empati dan perhatiannya terhadap pasien yang mengeluhkan sakitnya. Rasa empati dan perhatian yang diberikan anak yang memainkan peran dokter tersebut dapat menstimulasi pembentukan akhlak anak.

2) Bermain memberikan dunia khayal yang dapat dikuasai

Bermain dalam dunia khayal untuk anak usia dini, juga membutuhkan kemampuan berpikir. Ketika seorang anak berkhayal menjadi seekor burung. Ia tentunya harus memiliki pengetahuan tentang binatang burung dan bertingkah laku seperti burung. Contohnya anak akan merentangkan tangannya, seakan-akan tangannya adalah sayap burung. Ia akan berpura-pura terbang seperti burung. Sejumlah pengetahuan diperlukan anak ketika bermain dalam dunia khayalnya. Pengetahuan yang dimilikinya tentang perilaku burung, memberikan kesempatan pada anak untuk bebas mengekspresikan dunia khayalnya melalui pengetahuan yang dimilikinya.

Dalam berkhayal menjadi burung, anak akan belajar bagaimana rasanya menjadi burung yang sering diburu manusia atau ditangkap untuk dimasukkan ke dalam sangkarnya. Hal ini membentuk rasa kasih sayang anak kepada binatang ciptaan Tuhan, untuk tidak melukainya dan dapat menjaga kelestariannya.

3) Bermain merupakan cara anak untuk menyelidiki sesuatu

Bermain dapat bermanfaat bagi anak untuk menyelidiki sesuatu. Anak yang sedang bermain masak-masakan, biasanya akan menggunakan daun-daun yang ada di sekitarnya untuk dijadikan sayur yang akan dimasak. Untuk memasak, anak akan mencari berbagai jenis bijibijian yang ditemuinya untuk ditumbuk, seakan-akan menjadi bumbu dapur untuk memasak. Anak akan menemui berbagai jenis bijian yang berbeda-beda. Ada yang lembut dan mudah ditumbuk, sebaliknya ada juga yang keras dan sulit ditumbuk. Ketika menemui biji yang sulit ditumbuk, ia akan mencari tahu mengapa biji tersebut keras dan sulit ditumbuk. Muncul rasa ingin tahu anak dan keinginan untuk menyelidiki segala sesuatu mengenai biji tersebut. Rasa ingin tahu dan keinginan untuk menyelidiki tersebut akan menambah pengetahuan anak mengenai tumbuhan dan biji-bijian.

Berbagai jenis biji-bijian yang ditemui anak pada saat bermain, menstimulasi pembentukan akhlak anak melalui arahan dari guru tentang pentingnya menjaga kelestarian lingkungan hidup, peduli terhadap alam sekitar dan tidak merusak lingkungan alam, agar berbagai jenis tumbuhan yang ada tetap lestari. 
4) Bermain merupakan cara dinamis untuk belajar

Sesuai dengan konsep pembelajaran anak usia dini, belajar seraya belajar, pada saat bermain anak akan belajar berbagai konsep ilmu pengetahuan dan memahami pentingnya memiliki perilaku yang baik terhadap sesama.

5) Bermain menjernihkan pertimbangan anak

Bermain sebagai penjual dan pembeli akan memberikan pengetahuan kepada anak mengenai proses jual beli kepada anak. Anak yang berperan sebagai penjual akan mempertimbangkan barang mana yang dijual dengan harga yang mahal karena lebih bagus dan barang mana yang dijual dengan harga yang lebih murah karena kurang bagus.

Berperan sebagai penjual juga melatih anak untuk memiliki kejujuran dalam menjual barang, anak diajarkan untuk menjual barang yang baik, karena menjual barang yang rusak akan merugikan orang lain. Dimana sikap jujur adalah bagian dari akhlak yang baik.

Pertumbuhan dan perkembangan anak usia dini dapat berjalan optimal melalui berbagai stimulasi dalam bentuk bermain seraya belajar yang merupakan prinsip belajar dalam PAUD.

\section{PERAN PAUD DALAM TUMBUH KEMBANG ANAK USIA DINI}

Berdasarkan Undang-undang Nomor 20 Tahun 2003 tentang Sistem Pendidikan Nasional berkaitan dengan Pendidikan Anak Usia Dini, pada pasal 28 ayat 1 yang berbunyi "Pendidikan Anak Usia Dini diselenggarakan bagi anak sejak lahir sampai dengan enam tahun dan bukan merupakan prasyarat untuk mengikuti pendidikan dasar." Selanjutnya pada Bab I pasal 1 ayat 14 ditegaskan bahwa Pendidikan Anak Usia Dini adalah suatu upaya pembinaan yang ditujukan kepada anak sejak lahir sampai dengan usia enam tahun yang dilakukan melalui pemberian rangsangan pendidikan untuk membantu pertumbuhan dan dan perkembangan jasmani dan rohani anak agar memiliki kesiapan dalam memasuki pendidikan lebih lanjut (Depdiknas, USPN, 2004:4).

Yuliani Nurani Sujiono (2013: 42) menyebutkan bahwa secara umum, tujuan pendidikan anak usia dini adalah mengembangkan potensi anak sejak dini sebagai persiapan untuk hidup dan dapat menyesuaikan diri dengan lingkungannya. Secara khusus kegiatan pendidikan bertujuan agar:

1. Anak mampu melakukan ibadah, mengenal dan percaya akan ciptaan Tuhan dan mencintai sesama.

Anak usia dini dikenalkan kepada Tuhannya, melalui kegiatan ibadah dan mencintai makhluk ciptaan Tuhan.

2. Anak mampu mengelola keterampilan tubuhnya termasuk gerakan yang mengontrol gerakan tubuh, gerakan halus dan gerakan kasar, serta menerima rangsangan sensorik.

Anak distimulasi agar dapat mengembangkan keterampilan yang berhubungan dengan gerak tubuhnya, yang bermanfaat bagi kehidupannya sehari-hari, bersosialisasi dengan orang lain dan keterampilan yang berkaitan dengan persiapannya masuk sekolah dasar.

3. Anak mampu menggunakan bahasa untuk pemahaman bahasa pasif dan dapat berkomunikasi secara efektif, yang bermanfaat untuk berpikir dan belajar.

Anak dapat berinteraksi dengan baik dengan orang lain dengan memahami apa yang disampaikan oleh orang lain dan dapat memberi tanggapan/jawaban terhadap pertanyaan dari orang lain dalam konteks pembelajaran yang bermanfaat bagi perkembangannya. Contohnya, ketika ditanya oleh guru mengenai pekerjaan orang tuanya anak dapat menjawab nama 
pekerjaan orang tuanya, bahkan akan lebih baik lagi apabila anak dapat menjelaskan seperti apa bentuk pekerjaan yang dilakukan oleh orang tuanya.

4. Anak mampu berpikir logis, kritis, memberikan alasan, memecahkan masalah dan menemukan hubungan sebab akibat.

Contohnya disini adalah anak dapat menjelaskan mengenai pentingnya makan makanan bergizi, bagi pertumbuhannya dan dapat menjawab pertanyaaan dari guru yang berkaitan dengan hal tersebut.

5. Anak mampu mengenal lingkungan alam, lingkungan sosial, peranan masyarakat dan menghargai keragaman sosial dan budaya serta mampu mengembangkan konsep diri, sikap positif terhadap belajar, kontrol diri dan rasa memiliki.

Anak mengerti dimana ia tinggal dan bagaimana harus berperilaku dalam lingkungan sosialnya, contohnya dalam perilakunya sehari-hari, anak memahami perbedaan latar belakang budaya yang dimiliki oleh teman-temannya yang berbeda-beda dan menghargai perbedaan tersebut. Anak juga dapat berperilaku sopan sesuai dengan kebiasaan yang berlaku di lingkungannya.

6. Anak memiliki kepekaan terhadap irama, nada, birama, berbagai bunyi, bertepuk tangan, serta menghargai hasil karya yang kreatif.

Anak dapat diajak bernyanyi, menari dan berbagai kegiatan lainnya yang berkaitan dengan pengenalan anak terhadap musik dan kreatifitasnya.

Optimalisasi tumbuh kembang anak usia dini yang dilakukan di PAUD tercantum dalam Permendiknas nomor 58 tahun 2009. Menurut Permendiknas nomor 58 tahun 2009 mengenai standar perkembangan anak usia dini, lingkup perkembangan anak usia dini, terbagi atas nilainilai agama dan moral, motorik (motorik kasar dan motorik halus), kognitif, bahasa dan sosial emosional.

\section{Perkembangan Kognitif}

Perkembangan kognitif adalah perkembangan kemampuan berpikir anak. Menurut Piaget dalam Suyadi (2009: 102), tahapan perkembangan kognitif terbagi dalam 4 tahapan, yaitu:

a. Tahap Sensorimotor (0-18 bulan)

Pada usia 0-18 tahun kemampuan berpikir anak berkembang melalui indera sensoriknya. Anak mulai mengenal berbagai macam hal dari lingkungannya melalui alat inderanya, contohnya anak dapat membedakan suara ibunya atau suara orang lain dari indera pendengarannya. Ia dapat mengenali wajah ibunya dan menangis ketika tidak mengenali wajah orang lain yang tidak dikenalinya, melalui indera penglihatannya. Untuk mendapatkan kemampuan yang fungsional yang maksimal, anak perlu lebih banyak kontak langsung dengan lingkungannya. Dengan memberikan treatmen sensorik, yaitu memberikan perlakuan terarah dan teratur pada indera penglihatan, pendengaran, pembau, perasa dan peraba anak dapat memaksimalkan dan memanfaatkan semua sumber-sumber informasi melalui alat inderanya (Sutan Surya, 2007).

b. Tahap Praoperasional (18 bulan- 6 tahun)

Pada tahapan ini kemampuan berpikir anak berkembang dengan cara melakukan langsung/praktek langsung mengenai segala sesuatu. Anak tidak akan memahami sesuatu, sebelum ia mempraktekkan langsung kegiatan tersebut. Contohnya ketika seorang anak belajar mengancingkan bajunya. Ia tidak akan paham mengancingkan baju, apabila hanya diberikan penjelasan secara lisan, namun ia akan tahu dan belajar 
bagaimana cara mengancingkan baju dengan cara mempraktekkan langsung bagaimana mengancingkan bajunya sendiri.

Selain itu juga, anak pada usia ini akan belajar lebih baik dengan cara memanipulasi sebuah obyek untuk mencapai tujuannya. Disini, anak dapat memanfaatkan berbagai macam obyek/benda yang ada disekitarnya sesuai dengan keinginannya.

Anak pada usia ini masih bersikap egosentris, dimana ia tidak dapat dengan mudah memahami sudut pandang/pikiran orang lain. Segala sesuatu hanya terfokus pada keinginannya dan tidak memperdulikan pendapat maupun pikiran orang lain. Dalam pemikiran anak yang masih berada pada tahapan praoperasional, setiap orang berpikir sama dengan dirinya, oleh karena itu harus mengikuti jalan pikirannya.

Karakteristik lainnya yang terdapat pada anak yang berada pada tahapan praoperasional adalah pemusatan. Pemusatan berhubungan dengan kemampuan anak dalam mengklasifikasikan dan mengurutkan. Anak pada tahapan ini senang melakukan kegiatan yang didalamnya terkandung kegiatan mengklasifikasikan dan mengurutkan sesuatu.

Dalam bukunya Konsep Dasar Pendidikan Anak Usia Dini, Yuliani Nurani Sujiono. (2013) menyebutkan tahapan praoperasional pada anak juga ditandai dengan kesukaran yang dihadapi oleh seorang anak dalam membalikkan pemikiran (reversibilitas). Reversibilitas adalah kemampuan mengikuti suatu pemikiran dan kembali lagi pada titik awal. Ia juga mempunyai kesukaran dalam memberikan alasan yang masuk akal mengenai transformasi. Anak cenderung untuk berkonsentrasi pada salah satu unsur dan bukan pada proses transformasi dari suatu obyek atau benda yang sedang berlangsung dari satu bentuk ke bentuk lainnya.

c. Tahapan Kongkrit Operasional (6 tahun-12 tahun)

Tahapan ini ditandai proses berpikir anak melalui belajar dengan benda yang kongkrit/nyata. Anak pada usia ini akan mampu memahami suatu benda, apabila penjelasan yang diberikan disertai dengan wujud kongkrit benda yang dijelaskan.

d. Tahapan Formal Operasional (12 tahun ke atas)

Tahapan formal operasional adalah tahapan kemampuan berpikir tertinggi menurut Piaget. Pada usia 12 tahun keatas, anak sudah dapat berpikir abstrak, ia dapat membayangkan konsekuensi/akibat yang akan terjadi padanya, bila ia melakukan sesuatu, tanpa perlu melakukannnya terlebih dahulu. Selain itu juga, anak sudah dapat berpikir logis dan analitis.

\section{Perkembangan Nilai-nilai Agama dan Moral}

Seiring dengan perkembangan koginitifnya, anak usia dini diharapkan mulai memahami aturan dan norma yang dikenalkan oleh guru dan orang tua melalui penjelasan sederhana, pembiasaan dan contoh tauladan. Tujuan pendidikan dan pengembangan moral anak menurut Adler (dalam Otib Satibi Hidayat, 2008) adalah dalam rangka pembentukan kepribadian yang harus dimiliki oleh manusia, seperti:

1) Dapat beradaptasi pada berbagai situasi dalam relasinya dengan orang lain dan dalam hubungannya dengan berbagai kultur

2) Selalu dapat memahami sesuatu yang berbeda dan menyadari bahwa dirinya memiliki dasar pada identitas kulturnya

3) Mampu menjaga batas yang tidak kaku pada dirinya, bertanggung jawab terhadap bentuk batasan yang dipilihnya dan terbuka pada perubahan 
Penguasaan dari tujuan tersebut adalah adanya keterampilan afektif anak itu sendiri, untuk merespon orang lain dan merespon pengalaman baru yang dialaminya serta memunculkan perbedaan dalam kehidupan teman-teman di sekitarnya.

\section{Perkembangan Motorik}

Perkembangan motorik merupakan perkembangan pengendalian gerakan jasmaniah melalui kegiatan pusat syaraf, urat syaraf dan otot terkoordinasi (Hurlock: 1998). Keterampilan motorik anak terdiri atas keterampilan motorik kasar dan keterampilan motorik halus.

Motorik kasar berkaitan dengan aktivitas fisik/jasmani dengan menggunakan otot-otot besar, seperti otot lengan, otot tungkai, otot bahu, otot punggung dan otot perut yang dipengaruhi oleh kematangan fisik anak. Motorik kasar dilakukan dalam bentuk berjalan, berjinjit, melompat, meloncat, berlari, dan berguling. Perkembangan motorik berbeda dari setiap individu, ada anak yang perkembangan motoriknya sangat baik, seperti atlet, namun ada juga yang memiliki keterbatasan fisik. Selain itu juga dipengaruhi oleh perbedaan jenis kelamin (gender).

Motorik halus adalah adalah gerakan yang menggunakan otot-otot halus atau sebagian anggota tubuh tertentu, yang dipengaruhi oleh kesempatan untuk belajar dan berlatih. Setiap anak mampu mencapai tahap perkembangan motorik halus yang optimal asal mendapatkan stimulasi tepat.

Perkembangan motorik halus adalah kemampuan yang berhubungan dengan keterampilan fisik yang melibatkan otot kecil dan koordinasi mata-tangan. perkembangan otot-otot pada tangan anak untuk melakukan beberapa gerakan yang membutuhkan koordinasi. Contoh keterampilan motorik halus anak adalah menggenggam, menjimpit, memegang, merobek, menggunting, menulis, menggambar, menyusun balok, bermain puzzle dan lain sebagainya.

\section{Aspek Perkembangan Sosio-Emosional}

Pola perilaku sosial yang terlihat pada masa anak-anak, seperti yang diungkap oleh Hurlock (1998:252) yaitu: kerjasama, persaingan, kemurahan hati, hasrat akan penerimaan sosial, simpati, empati, ketergantungan, sikap ramah, sikap tidak mementingkan diri sendiri, meniru, perilaku kelekatan.

Erik Erikson (1950) dalam Papalia dan Old (2008:370) seorang ahli psikoanalisis mengidentifikasi perkembangan sosial anak: (1) Tahap 1: Basic Trust vs Mistrust (percaya vs curiga), usia 0-2 tahun. Dalam tahap ini bila dalam merespon rangsangan, anak mendapat pengalaman yang menyenamgkan akan tumbuh rasa percaya diri, sebaliknya pengalaman yang kurang menyenangkan akan menimbulkan rasa curiga; (2) Tahap 2 : Autonomy vs Shame \& Doubt (mandiri vs ragu), usia 2-3 tahun. Anak sudah mampu menguasai kegiatan meregang atau melemaskan seluruh otot-otot tubuhnya.

Anak pada masa ini bila sudah merasa mampu menguasai anggota tubuhnya dapat meimbulkan rasa otonomi, sebaliknya bila lingkungan tidak memberi kepercayaan atau terlalu banyak bertindak untuk anak akan menimbulkan rasa malu dan ragu-ragu; (3) Tahap 3 : Initiative vs Guilt (berinisiatif vs bersalah), usia 4-5 tahun.

Pada masa ini anak dapat menunjukkan sikap mulai lepas dari ikatan orang tua, anak dapat bergerak bebas dan ber interaksi dengan lingkungannya. Kondisi lepas dari orang tua menimbulkan rasa untuk berinisiatif, sebaliknya dapat menimbulkan rasa bersalah; (4) Tahap 4 : industry vs inferiority (percaya diri vs rasa rendah diri), usia 6 tahun - pubertas.

Anak telah dapat melaksanakan tugas-tugas perkembangan untuk menyiapkan diri memasuki masa dewasa. Perlu memiliki suatu keterampilan tertentu. Bila anak mampu 
menguasai suatu keterampilan tertentu dapat menimbulkan rasa berhasil, sebaliknya bila tidak menguasai, menimbulkan rasa rendah diri.

\section{Perkembangan Bahasa}

Pada dua tahun pertama dalam kehidupan bayi dan anak pindah dari ucapan prabahasa ke penggunaan bahasa. Pada usia 2 tahun anak pindah dari ujaran telegrafis. Dalam hal ini, ia mampu menggunakan kalimat yang lebih panjang dan lebih sempurna. Saat ini anak belajar aturan morfologi meskipun sering mengalami kesalahan karena sering menggunakan perampatan yang berlebihan. Disamping itu, ia belajar menyusun kalimat dengan memperjelas susunan kata yang lebih baik. Kalimat mereka semakin kompleks saat mereka mengembangkan kosa kata dan ujaran ekspresif.

Pada usia 3 tahun, anak mulai memahami dan menggunakan aturan percakapan. Mereka mampu membicarakan hal-hal yang saat ini tidak ada dihadapannya. Akibatnya, mereka dapat menggunakan bahasa saat bersandiwara atau pembicaraan tentang hal-hal yang dihayalkan. Pada saat kesadaran prasosial anak berkembang, anak usia 4 tahun juga dapat memvariasikan gaya bicaranya ketika berbincang-bincang dengan berbagai lawan bicara, seperti terhadap anak yang lebih muda, sebaya, atau dewasa.

Proses perkembangan bahasa usia 6 sampai 8 tahun mirip dengan perkembangan motorik anak. Pada usia ini anak menghaluskan dan mengembangkan bahasa yang dipelajari pada tahuntahun prasekolah. Pada masa ini anak telah menguasai dasar-dasar sintaksis dan semantic, yaitu mereka telah belajar bagaimana kalimat dibentuk dan kata-kata digunakan untuk mengkomunikasikan makna. Namun demikian mereka masih bingung dengan makna dan penggunaan kata.

Dengan demikian, PAUD memiliki peran yang sangat penting dalam tumbuh kembang anak usia dini, karena dapat memfasilitasi seluruh aspek-aspek perkembangan yang ada pada anak usia dini agar berkembang secara optimal.

\section{KESIMPULAN}

Anak usia dini adalah anak yang berada pada usia emas perkembangannya, dimana seluruh aspek perkembangannya tersebut akan tumbuh dan berkembang secara optimal apabila diberikan stimulasi yang tepat.

Pemberian stimulasi yang optimal salah satunya dapat diperoleh anak usia dini melalui PAUD. PAUD merupakan lembaga pendidikan yang memiliki standar tenaga pendidik dan kependidikan yang mengetahui mengenai tumbuh kembang anak usia dini dan bagaimana menstimulasinya sesuai dengan tahapan perkembangan dan karakteristik perkembangan anak di setiap usianya.

Diharapakan dengan mengikuti PAUD, anak-anak yang berada pada rentang usia dininya sekarang akan menjadi generasi generasi muda yang produktif dan kompetitif secara global serta dapat membangun masa depan bangsanya dengan lebih baik lagi.

\section{DAFTAR RUJUKAN}

Anggani, Sudono. 2006. Sumber Belajar dan Alat Permainan. Jakarta: Grasindo Crain, William. 2007. Teori Perkembangan; Konsep dan Aplikasi. Yogyakarta: Pustaka Pelajar Hurlock, Elizabeth B. 1998. Psikologi Perkembangan, terj. Istiwidiyanti dan Soedjarwo. Jakarta: Erlangga 
Hurlock, Elizabeth B. 2013. Perkembangan Anak. Jilid 1. Edisi Keenam, terj. Meitasari Tjandrasa dan Muslichah Zarkasih. Penerbit Erlangga: Jakarta

Moeslichatoen, R. 2004. Metode Pengajaran Di Taman Kanak-Kanak. Jakarta: Rineka Cipta.

Otib Satibi Hidayat. 2008. Metode Pengembangan Moral dan Nilai-Nilai Agama. Jakarta: Universitas Terbuka.

Papalia, Diane E, Etc. 2008. Human Development (Psikologi Perkembangan, terjemahan A. K. Anwar). Jakarta: Kencana Prenada Media Grup

Shoba Dewey Chugani. 2009. Anak Yang Bermain, Anak Yang Cerdas. Jakarta: PT. Gramedia Pustaka Utama.

Sutan Surya. 2007. Melejitkan Multiple Intelligence Anak Sejak Dini. Yogyakarta: Penerbit Andi.

Suyadi. 2009. Ternyata, Anakku Bisa Kubuat Genius. Yogyakarta: Power Books.

Suyadi. 2009. Permainan Edukatif Yang Mencerdaskan. Yogyakarta: Power Books.

Yuliani Nurani Sujiono dan Bambang Sujiono. 2010. Bermain Kreatif Berbasis Kecerdasan Jamak. Jakarta: PT. Indeks

Yuliani Nurani Sujiono. 2013. Konsep Dasar Pendidikan Anak Usia Dini. Jakarta: PT. Indeks 